UDC 821.111.03-1=163.41

\author{
Jelisaveta Milojević \\ University of Belgrade \\ Faculty of Philology \\ Belgrade, Serbia
}

\title{
UNTYING THE KNOT: SHAKESPEARE'S SONNETS 27 AND 144 IN SERBIAN TRANSLATIONS
}

\begin{abstract}
This paper deals with the Serbian translations of Shakespeare's Sonnets 27 and 144. These sonnets have been chosen because of their striking polysemy and consequent translation issues. Analysis of the original is considered and different translations are compared and assessed. My translations are also presented, being published for the first time in this volume of the BELLS journal. General questions are put forward and answered: Why the sonnets, again? Why translate that which has already been translated? Can a person with no knowledge of the source language translate poetry with the assistance of a prose translation done by someone who does know that language? Where are the limits of poetic license in versification? Are the critic and translator to be the same person? Is it possible to criticise a translation even if one has no sovereign control over the source language? Why is translation criticism necessary? As the importance of such criticism is defended in this paper, presented to the readers as a form of apologia and for the purposes of illustration is a side-by-side analysis of Shakespeare's Sonnets 27 and 144 and their respective Serbian translations, including my own.
\end{abstract}

Key words: sonnets, analysis, translation, translation criticism, licentia poetica

E-mail address: jelce@EUnet.rs 


\section{Introduction}

Not 50 years since Shakespeare's sonnets were released to the reading public in Serbian, I translated another edition of the sonnets: a collection of Shakespeare's "great sonnets" (Milojević, J. Šekspir: Soneti. Belgrade: Faculty of Philology, 2012).

In this paper, different versified translations of Sonnets 27 and 144 are compared to the original and analysed according to their subject matter, figurative techniques, rhythm, metre, and structure, mostly in terms of how these elements relate to translation. In addition, general questions are raised, such as: Why the sonnets, again? Why translate that which has already been translated? Can someone who has no knowledge of the source language translate poetry with the assistance of a prose translation done by someone who does know that language? Where are the limits of poetic license in versification? Are the critic and translator to be the same person? Is it possible to criticise the translation even if one has no sovereign control over the source language? Why is translation criticism necessary? As I consider the freedom to indulge in such criticism meaningful, I present to the readers as a form of apologia and for the purposes of illustration a side-by-side analysis and criticism of versified translations of Shakespeare's Sonnets 27 and 144, so that readers may discern for themselves the lemons from the gifts. ${ }^{1}$

Why the sonnets, again? Why translate that which has already been translated? There are no fewer than three answers. Translating poetry is among the most demanding of translation tasks and, as such, can always be done differently or better, given that a translation is but an approximation of the ideal and not a realisation of that ideal. On the other hand, new translations are necessary because language itself is dynamic in its historical and social development such that at certain moments communication between the source and target languages becomes strained or impossible. There exists another, perhaps more important, reason: it is the duty of every specialist and translator to stand, authoritatively, in defense of the poet - the author of the original-and correct the mistakes of their predecessors, insofar as they have failed the original. We can only imagine, as a result of poor translations which fall short of the original, how much inaccuracy is borne by works of literary criticism and literary history that

1 In Shakespeare's play Love's Labours Lost (Act V, Scene ii) Hector was proclaimed to have been given a gift—which Berowne interjects was a lemon, i.e. something disappointing. 
do not engage with works in the original but rely on translations without suspecting them to be wanting; the same is true of theatre: insufficient translations are adopted by directors, actors and then the public, thus perpetuating inadequate and poor interpretations. "A criminal act is always that which has occurred, has had an impact and repercussions, of relatively short duration, at one time in the past. A poor translation has an impact and repercussions which occur in the future, for an endless period of time" (Živojinović, 1981: 273). Such reasoning prompted me to make my own attempt at translating Shakespeare's sonnets. "A poor translation can only be overcome by a good one. There is no opinion that can take the place of creation itself." (Živojinović, 1981: 267).

Why the sonnets, again, in Serbian? Or, in other words: Why is translation criticism necessary? An answer, with annotation, may be framed within the following citation: "A poor translation would possibly deserve no more attention than a weak original work if it weren't a question of it being a false representation of the original. A weak writer speaks only in his own name, while a bad translator lends his voice to even the great poets. This is why translation criticism has an important task to warn readers as to how true to the original the text they are being offered is. The critic who engages in reviewing a translation is the only defense of the defenseless author of the original" (Konstantinović, 1981: 123). "By reading a poor translation the reader most often lives in the false belief that the poet, whose greatness he does not see, has created an ephemeral work, of importance to only his or her contemporaries or compatriots" (Konstantinović: 1981: 122, 123). I would have had such convictions as a reader of Shakespeare's sonnets had I not been consumed by two doubts: that Shakespeare wrote anything ephemeral and that the extant translations were flawless and that I wasn't in a position to peer at such heights. My doubts dissolved the moment I took up the original myself - the poems revealed themselves in their true glory, and the extant translations were but the shadow of a shadow. Thence my decision to take a stand to defend the poet as far as my academic and poetic strength would allow. Thence, as well, my decision to print the original sonnets alongside the translations. Thence, again, the decision to assess through critical analysis the sonnet corpus that has been translated into Serbian thus far and to offer my own translation solutions, which, if successful, will speak much more eloquently than criticism.

To review some of the more important ideas from the introduction to my translations: It is my opinion that Shakespeare was a poet in his dramas 
as well as a dramatic writer in his poems-how much of each in which instance is a matter of degree: of being more or less rather than one precluding the other. When Shakespeare's sonnets are recited, it is noted that they have been penned by a hand with a flair for drama (see, for example, Sonnet 46, which begins with the line, "My eye and heart are at mortal war" and has a clear exposition at the beginning; undergoes conflict, development and climax in the second 'act', i.e. in the second quatrain; reaches epiphany in the third 'act', i.e. third quatrain and comes to an effective resolution in the last distich). As a second example of the connection between the poetic and dramatic, I will cite the example of Sonnet 66, which begins with the line, "Tired with all these, for restful death I cry," and which, in verse, thus through the medium of poetry, shapes and powerfully evokes the theme of Hamlet's dramatic monologue, "To be or not to be". In this instance, in this context, I would like to point out the following: I think that this idea of the dramatic and poetic in Shakespeare's opus could be fruitful in bringing his complete works to the stage: if the opus were to be cut vertically, so that none of the dramas or poems were presented separately but all of the dramatic works and poems were to be assembled in one place related by theme (love, jealousy, beauty, disappointment, revenge, death, etc.), it would be possible to speak of variations on a given theme or themes so that, in such a staged presentation of Shakespeare's works, even the sonnets would naturally find their place-as it is, theatre directors find the sonnets to be undramatisable because of the lack of action (Nikita Milivojević, personal communication), which is why we do not often see them in the theatre. The Sonnets, however, were premiered on the stage of the National theatre in Belgrade on 26 February 2014-marking the first time Shakespeare's Sonnets were performed in Serbia (the translation used was my own). The director, Aleksandar Nikolić, proved such a feat possible through eloquent theatrical sensibility: the Sonnets are already heavily dramatically charged in that they are expressions of deep inner emotional states and conflicts that manifest a strong need to be verbalised and communicated to an audience, as is the case with a soliloquy in a play (compare, for example, the "To be or not to be" Hamlet soliloquy and Sonnet 66). What is more, this idea, as I have put it forward, would also benefit literary criticism, which as far as I know has not considered Shakespeare in this way-I think that only in this way could it have complete insight into Shakespeare's poetic vision. 
The themes of the Sonnets vary but are all vaulted by the theme of love, which is depicted in an unconventional, anti-Petrarchan and surprisingly complex way so that we may say that the sonnets present a kind of modern love poetry. Shakespeare plays with gender roles, speaks openly about sexual desire and sexual intercourse, glorifies and parodies beauty, describes the temptations of passionate and carnal love, considers Platonic and idealized love and explores man's experience of physical and spiritual love, procreation, everlasting love, disappointment, pining, doubts and fears, hope and imagination, redemption and forgiveness, compassion, jealousy, triumphant love, etc. Figurative techniques, imagery and tone are crafted according to the different themes. In recent decades, scholarship of the sonnets has focused almost exclusively on the decomposition of the sonnets and the use of rhetorical figures, such as metaphor, metonymy, allusion, alliteration, assonance, antithesis, synecdoche, personification, internal rhyme, word play, double entendre, multiple associations, anaphora, etc. Examples of such scholarship includes that released by major publishing houses Cambridge University Press (Sonnets, CUP:1966) and Penguin (Sonnets, Penguin: 1986). For examples of polysemy and homonymy we refer the reader to analysis of Sonnet 20 (verses 1-2, verse 10), Sonnet 27 (verses 13-14), Sonnet 144 (polysemy is found in almost every verse); metonymy, Sonnet 59; antithesis and synecdoche, Sonnets 12 and 116; alliteration, Sonnet 91 (verse 4) as well as Sonnets 30 and 55; assonance, Sonnet 55; anaphora, Sonnet 91 (verses 1, 2, 3, and 4); parallel structure within the verse, Sonnet 91 (verse 10); personification, Sonnets: 20 (verse 10), 27 (verse 12), 55, 65, 73, 2, 59); word play and double entendre, Sonnets 144 (the last quatrain and the couplet), 75, 35 (verse 9), 20 (verse 1, 2); ambiguity and word play, Sonnet 20 (verse 7), Sonnet 27 (couplet, verses 13, 14). The absence of elaborate stylistic technique and idiosyncrasy does not deprive the sonnets of their artistic potential and beauty - on the contrary, Shakespeare achieved great effect and beauty by the use of very simple poetic means and structure, strong emotional cohesion and transposition (for example, Sonnet 116). A few more words on style: all stylistic analysis-whether an end in itself or carried out for the purpose of explication and translation-should be preceded by solid and comprehensive research into the meaning of those words that had different meaning in early modern English (note, for example, that Shakespeare was the first to use the word imaginary in the sense of imaginative: Sonnet 27, verse 9 , or that the word shadow, meaning the same as 'senka' in present 
day English, meant in Shakespeare's day 'insubstantial image': Sonnet 27, verse 10). This should be sine qua non, however, we witness many failures - the original being failed by the translators (see, for example, the couplet verses of Sonnet 27 in Angjelinovic's and Raickovic's translations). A translator should be guided by a healthy skepticism: collocative and associative meanings change over time. Apart from the ignorance of the translator there exist additional objective difficulties having to do with the original text: some of the sonnets, or sections thereof, are intentionally polysemous (cf. Sonnet 20, verses 1-2; Sonnet 27, verses 13-14 (Sonnets, CUP, 1996)). Consequently, different readings are possible, which in turn affects translation. We refer the reader to the following quotation: "Poetic work is often insufficiently transparent and it should remain such in translation" (Konstantinović, 1981:126).

Almost all of the sonnets comprise three quatrains of four-line stanzas and a final couplet composed in iambic pentameter; the rhyme scheme is $a b a b c d c d$ efef $g g$. This is also the meter used extensively in Shakespeare's plays. Because this article is concerned with the translation of Shakespeare's sonnets, I shall add that having considered the rhythm favoured by English poetry, the rhythmic essence of the language is unique - and it follows that the essence of the Serbian language has its own rhythm (it is trochaic), which must be respected in the translation because in order for a translation to resonate with the rhythmic essence of the target language, it must pulse in that rhythm only. Hence any insistence on the literal transference of the rhythm and metre from the source into the target language makes no sense: the translated poem must have the vibrations of the linguistic essence of the language into which it is being translated.

Regarding the structure of Shakespeare's sonnets and the essential connection between form and meaning, I would like, from my own perspective as translator, to point out the following aspect of my experience. Taken by the beauty of one distich, I began to translate it at once, unable to wait for the moment it would 'have its turn,' i.e. by beginning with the first quatrain then proceeding to the second, then third. It happened that despite my enthusiasm and what appeared to be the self-contained meaning and aesthetic qualities of a single distich, I was unable to arrive at solutions and problems endured. The following became apparent, which I believe to be of phenomenological value: translation is a journey, undertaken hand in hand with the poet, and it has its beginning: both intellectual and emotional, its duration, and its end, and the poetic hand-holding ought 
to give way to trust, empathy and good will; in such a way, the translator, alongside the poet, undergoes catharsis and finishes the journey with a feeling of happiness and the translation grows only in those places where things, according to the poet's foresight, ought to grow and only when it is time for them to grow. Prosodic translation is an act of re-creation, making again, and it implies a respect for the natural flow of things: 'hop and skip' translating is unnatural in this respect.

Licentia poetica, also known as 'poetic freedom,' is most often a euphemism which stands for the distortion of facts, oversimplification, the stylization or metaphorical condensation of images, the omission or addition of linguistic material, grammar distortion and the verbal reconfiguration of the original text with the intention to renew or improve the inherent content of the original. Those who take liberties with poetic freedom, consciously or not, assume that this is entirely the discretionary right of the poet-translator and that this must be tolerated and approved of by the public. Addressing the poet's understanding of translation, Milovan Danojlić says: "According to that understanding, the original is not considered a protected prototype which must at all costs be preserved and transplanted, but is rather considered a challenge, a stimulus, a model according to which comparable poems are to be written... It was important to leave as personal a mark on the new version as possible, breathe life into it, enable it to have its own aesthetic function. The enterprise was only as alluring and worthy of attention as the personality undertaking it was interesting" (Danojlić: 1981: 247-248). Examples of poetic freedom, going so far as to become improvisations, appropriations and failures to reach the meaning of the original can be found in the examples of the side-by-side analysis of several versified-translations of Shakespeare's sonnets which I have presented in this paper. It was assumed by the editors and publishers that only literary experts and poets should translate the works of poets and that, insofar as there was a choice, the preference in translation was to be given to poets. It is my opinion, after serious and comprehensive analysis of versified-translation, that poets cannot translate or let the original sing through them without a thorough knowledge of the source language, and I think, furthermore, that both such a knowledge and a gift for poetry must be united within the same person. 
2. Critical assesment of the translations of Sonnets 27 and 144

\subsection{Sonnet 27}

\section{William Shakespeare \\ Sonnet 27 \\ (New Penguin Shakespeare, 1986) \\ (New Cambridge Shakespeare, 1996)}

Weary with toil, I haste me to my bed, The dear repose for limbs with travail tired;

But then begins a journey in my head

To work my mind, when body's work's expired;

For then my thoughts (from far where I abide)

Intend a zealous pilgrimage to thee,

And keep my drooping eyelids open wide,

Looking on darkness which the blind do see;

Save that my soul's imaginary sight

Presents thy shadow to my sightless view,

Which, like a jewel (hung in ghastly night)

Makes black night beauteous, and her old face new.

Lo thus by day my limbs, by night my mind,

For thee, and for myself, no quiet find.

\section{Sonnet 27}

\section{Translated by Jelisaveta Milojević (unpublished)}

Umoran od posla postelji žurim,

Slatkom odmoru za telo palo,

Al' onda, mislima, na put jurim

I glava radi i kad je telo stalo.

Misli, iz daleka, gde prebivaju,

Sa žarom tad kreću tebe da pohode

I teške kapke one otvaraju

Pa gledam mrak koji slepi vide - 
Osim što, izmaštan mojom dušom, Tvoj nestvarni lik vidim slepim vidom, Dragulj što groznu tamu učini lepom A noć-staricu učini mladom.

Mog tela i moje duše nemira

Ja sam uzrok, a ti uzrok i namera.

\section{Sonnet 27 \\ Versified translation by Stevan Raičković (based on the prose translation by Živojin Simić) \\ (Beograd: Prosveta, 1966)}

Postelji žurim - iznuren od rada -

Miloj počivki umornih od puta;

Al' put po mojoj glavi počne tada,

Te posle tela - trud - po umu luta.

Polaze moje misli, žudnog toka,

Na hodočašće, tebi, koje sami,

I ne daju mi da sklopim ni oka,

Te kao slepi gledam, sam, u tami.

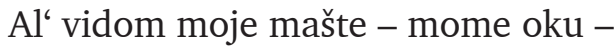

U tami tvoje drago lice gradim,

Koje ko dragulj sja kroz noć duboku

I učini je lepom, s likom mladim.

Po noći um moj, danju telo moje -

Zbog tebe nikad da se uspokoje. 


\title{
Sonnet 27
}

\section{Translated by Danko Angjelinović (Beograd: Kultura, 1966)}

\author{
U krevet žurim umoran od rada, \\ Da mi se mirom trudna uda slade,

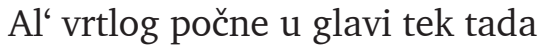 \\ I mozak radi kad tijelo prestade. \\ Jer tad mi miso iz dalekog stana \\ U hodočašće $k$ tebi željno ide, \\ I umornoj mi vjeđi ne da sana, \\ Već zurim u mrak, kog i slijepci vide; \\ Ti kad uskrsneš kroz duše mi plamen, \\ Ko mila sjena pred očima slijepim, \\ I kroz noć mračnu sjaš ko alem-kamen \\ I grozno lice noći praviš lijepim. \\ Tako mi noću miso, danju tijelo, \\ Rad tebe ne da mira vrijeme cijelo.
}

In the comparative analysis that will follow, only the couplet will be considered as it is arguably the linguistic and philosophical focal point of the sonnet and notoriously difficult from the point of view of translation. "For" is used twice in a double sense: the poet lies awake 'because of' the friend and 'for his sake'; so, 'because of' his devotion, he finds no quiet 'for' himself; 'on account of you, on account of myself'. "For" translates into Serbian as 'zbog' (indicating cause) and 'radi' (indicating intention). The meaning of the couplet is therefore the following: the poet cannot sleep because he is thinking about his friend and cannot stop the stream of thoughts; but, on the other hand, he himself instigates the thinking wishing to be with his friend in this way, for the purpose of being with his friend in his thoughts. This interpretation, based on analysis published in the editions of the sonnets published by CUP and Penguin, informed my translation. The translations by Raičković and Angjelinović are identical in both being incorrect.

Verses 13, 14: Lo thus by day my limbs, by night my mind, / For thee, and for myself, no quiet find. (Shakespeare);

Verses 13, 14: Po noći um moj, danju telo moje - / Zbog tebe nikad da se uspokoje. (Raičković); 
Verses 13, 14: Tako mi noću miso, danju tijelo, / Rad tebe ne da mira vrijeme cijelo. (Angjelinović);

Verses 13, 14: Mog tela i moje duše nemira / Ja sam uzrok, a ti uzrok i namera. (Milojević).

\section{2 Critical assesment of the translations of Sonnet 144}

This sonnet is even more strikingly polysemous and thus a challenge for the translator.

\section{William Shakespeare}

\section{Sonnet 144 \\ (New Penguin Shakespeare, 1986) \\ (New Cambridge Shakespeare, 1996)}

Two loves I have of comfort and dispair, Which like two spirits do suggest me still:

The better angel is a man right fair

The worser spirit a woman colour'd ill.

To win me soon to hell, my female evil

Tempteth my better angel from my side, And would corrupt my saint to be a devil, Wooing his purity with her foul pride.

And whether that my angel be turn'd fiend

Suspect I may, but not directly tell;

But being both from me, both to each friend,

I guess one angel in another's hell:

Yet this shall I ne'er know, but live in doubt, Till my bad angel fire my good one out. 


\section{Sonnet 144}

Translated by Jelisaveta Milojević (unpublished)

Dve ljubavi imam - osećanja tesnac -

Dva duha, dva anđela, dva iskušenja:

Anđeo utehe je svetao muškarac, Anđeo očaja crna je žena.

Da me u svoj pakao što pre uvede Ljubavnica ljubavnika mi opčini -

Gordom, divljom strašću ona ga zavede

Želeći da anđela đavolom učini.

Hoće li anđeo postati đavo?

Bliski su a između nas daljina.

Slutim da hoće, al' ne znam zapravo -

Njemu je otvorena đavolja jazbina.

Moja će sumnja biti odagnana

Bude li im ljubav vatrom žigosana.

\section{Sonnet 144 \\ Versified translation by Stevan Raičković \\ (based on the prose translation by Živojin Simić) \\ (Beograd: Prosveta, 1966)}

Dve su ljubavi sad u mojoj volji, Duh zla i dobra ratuju u meni; Plavook mladić - anđeo je boji, A gori - žena sa mrakom u zeni. Da me otera u ad - svojoj tami Odvukla mi je anđela boljega I lepotom ga sada na greh mami Da u đavola pretvori i njega. Da l' je postao đavo on od one, Slutiti mogu, ali ne znam tačno. Oni su prisni, a mene se klone, Te mi oboje izgledaju mračno. Da li je tako, nikad neću znati Dok zli anđeo beljeg ne isprati. 


\section{Sonnet 144 \\ Translated by Danko Angjelinović \\ (Beograd: Kultura, 1963)}

Do dvije ljubavi - sreće i očaja,

Ko do dva duha iznad mene bdiju:

Bolji je anđel mladić prepun sjaja,

A gori žena, duh mračnih očiju.

Da otjera me u pako - zavodi

Ta ženska zlica mog dobrog anđela,

I čistog sveca na vraga navodi,

Nevinost da bi u bludnost zavela.

Da l' i moj anđel postade sotona,

Nekako slutim, ali ne znam pravo;

Od mene bježe, prisni on i ona,

I strah me: crn je i anđel i đavo

To nikad neću znat i dvojit stoga,

Dok moj zli anđel ne uzme dobroga.

We shall pinpoint few polysemous knots to be untied by a translator. Consider the following examples:

"What seems most striking in the polysemy of 144 is the ambivalence of 'love' in line 1 . Those 'two loves' must register as different modes of feeling - comforting and hopeless - until the second line makes them 'spirits'. Two kinds of loving are summed in two individuals (...), with 'love' at once emotion and the loved object. But 'the bad angel' represents only the 'dark' side of love (...)" (Introduction to the Sonnets, CUP, 1966:61)

Verses 1-2: Two loves I have of comfort and dispair,/Which like two spirits do suggest me still:/ (Shakespeare);

Verses 1-2: Dve ljubavi imam - osećanja tesnac -/ Dva duha, dva anđela, dva iskušenja:/ (Milojević);

Verses 1-2: Dve su ljubavi sad u mojoj volji,/ Duh zla i dobra ratuju u meni; (Raičković);

Verses 1-2: Do dvije ljubavi - sreće i očaja,/Ko do dva duha iznad mene bdiju: (Angjelinović). 
We shall also note that the word "suggest" means: 1 . prompt; 2 . tempt ('podstaći'; 'iskušavati'). The translations that approximate the original most are those of Milojević and Raičković whereas that of Angjelinović is the least successful—in fact, it completely misses the point.

Another example of polysemy is the following:

Verse 3: a man right fair (Shakespeare);

Verse 3: svetao muškarac, (Milojević);

Verse 3: Plavook mladić (Raičković);

Verse 3: mladić prepun sjaja (Angjelinvić).

"Right fair" means the following: 1. just, absolutely honest; 2. most beautiful (pale, blond).

Both meanings are suggested by the choice of the Serbian word 'svetao,' which has two meanings: 'fair-haired' or 'fair-skinned' but also 'chaste' and 'pure.' This other meaning was ignored by Raičković thus failing the original.

Yet another example:

Verse 8: "foul pride" (Shakespeare) becomes "gorda, divlja strast" (Milojević), "greh" (Raičković), and "bludnost" (Angjelinović).

"Foul pride" has multiple meaning and thus it is very complex and stylistically potent from the point of view of interpretation and connotation. It means: 1. horrible allure (implying beauty and sexual readiness), and 2. vanity. Both Raičković's and Angjelinović's translation miss the other meaning.

I have also chosen to focus on the last quatrain and the couplet because of their extreme richness in polysemy. Here is the original and three Serbian translations juxtaposed for comparison.

Verses 9-14: And whether that my angel be turn'd fiend/ Suspect I may, but not directly tell;/ But being both from me, both to each friend,/I guess one angel in another's hell:/ Yet this shall I ne'er know, but live in doubt,/ Till my bad angel fire my good one out. (Shakespeare);

Verses 9-14: Hoće li anđeo postati đavo?/ Bliski su a između nas daljina./Slutim da hoće, al' ne znam zapravo -/ Njemu je otvorena đavolja jazbina./Moja će sumnja biti odagnana / Bude li im ljubav vatrom žigosana. (Milojević);

Verses 9-14: Da l' je postao đavo on od one,/ Slutiti mogu, ali ne znam tačno./Oni su prisni, a mene se klone,/ Te mi oboje izgledaju 
mračno./ Da li je tako, nikad neću znati/ Dok zli anđeo beljeg ne isprati. (Raičković);

Verses 9-14: Da l' i moj anđel postade sotona,/ Nekako slutim, ali ne znam pravo;/Od mene bježe, prisni on $i$ ona,/I strah me: crn je $i$ anđel $i$ đavo/To nikad neću znat i dvojit stoga,/Dok moj zli anđel ne uzme dobroga. (Angjelinović).

The polysemy of "hell" (verse 12) includes: 1. the idea of suffering; 2. cunt (slang sense of hell); 3 . burrow; 4. vagina. The sexual implication of "fire," which also meant 'pox,' is obvious. The suggestion is also that the good angel has become an animal to be smoked out of its burrow (a lady's vagina) as well as an allusion to the proverb, "One fire drives out another." For an extensive explanation and commentary on Sonnet 144 the reader is referred to the "Introduction" in Sonnets, CUP, 1966:60. The translations by both Raičković and Angjelinović totally miss the point and thus fail the original.

\section{Conclusion}

In this paper, sections of Shakespeare's Sonnets 27 and 144 have been analysed alongside their Serbian translations. General questions have been put forward and answered: Why the sonnets, again? Why translate that which has already been translated? Can someone who has no knowledge of the source language translate poetry with the assistance of a prose translation done by someone who does know that language? Where are the limits of poetic license in versification? Are the critic and translator to be the same person? Is it possible to criticise a translation even if one has no sovereign control over the source language? Why is translation criticism necessary? As the importance of such criticism is defended in this paper, readers have been presented with side-by-side analysis of Shakespeare's Sonnets 27 and 144 and their respective Serbian translations serving as a form of apologia and the purposes of illustration.

Translating poetry is among the most demanding of translation tasks and, as such, can always be done differently or better, given that a translation is but an approximation of the ideal and not a realisation of that ideal. There exists another, perhaps more important, reason why translations may ever be performed anew: it is the duty of every specialist and translator to stand, authoritatively, in defense of the poet-the author of 
the original-and correct the mistakes of their predecessors, insofar as they have failed the original. "A criminal act is always that which has occurred, has had an impact and repercussions, of relatively short duration, at one time in the past. A poor translation has an impact and repercussions which occur in the future, for an endless period of time" (Živojinović, 1981: 273). This was the reasoning behind my decision to attempt translate Shakespeare's sonnets anew. A poor translation can only be overcome by a good one.

\section{References}

Bečanović-Nikolić, Z. (2009) "Shakespeare's Sonnets in Serbia", William Shakespeare's Sonnets, For the First Time Globally Reprinted, A Quatercentenary Anthology 1609-2009, Manfred Pfister and Jürgen Gutsch (eds.), Dozwil TG Switzerland, Edition Signathur, 587-596.

Blakemore Evans, G. (ed.) (1996). William Shakespeare: The Sonnets, Cambridge University Press .

Bertolino, N. (1981) "O kritici prevoda poetskih dela" in: Rajić, Lj. (ed.) Teorija i poetika prevođenja. Beograd: Prosveta, 159-176.

Booth, S. (ed.) (1977). Shakespeare's Sonnets. New Haven: Yale University Press. Crnjanski, M. "Šekspirovi soneti" in: Eseji (1983). Beograd: Nolit, 194-231. Danojlić, M. "Pesnik kao prevodilac" in: Rajić, Lj. (ed.) Teorija i poetika prevođenja (1981). Beograd: Prosveta, 243-260.

Elliot, T. S. (1932) Selected Essays. Faber \& Faber.

Hecht, A. (1996) "Introduction" in: Blakemore, E. G. (ed.), William Shakespeare: The Sonnets, Cambridge University Press, 1-28.

Ivir, V. (1978) Teorija i tehnika prevođenja. Sremski Karlovci: Karlovačka gimnazija "Shakespeare's Sonnets in Serbia", William Shakespeare's Sonnets, For the First Time Globally Reprinted, A Quatercentenary Anthology 1609-2009, Manfred Pfister and Jürgen Gutsch (eds.), Dozwil TG Switzerland, Edition Signathur, 587-596.

Kerrigan, J. (ed.) (1986). William Shakespeare: The Sonnets and A Lover's Complaint. Penguin Books.

Kerrigan, J. (1986). "Introduction" in: William Shakespeare: The Sonnets and A Lover's Complaint. Penguin Books, 7-63.

Klajn, H. (1964). Šekspir i čoveštvo. Beograd: Prosveta. 
Klajn, H. (1964). "Šekspir kod Jugoslovena" in: Klajn, H. Šekspir i čoveštvo, Beograd: Prosveta, 228-242.

Kokir, Z. (2003). Pet vekova engleskog soneta. Prepev: Zorana Kokir. Beograd: Gutenbergova galaksija.

Konstantinović, R. (1981)“O prevođenju poezije” in: Rajić, Lj. (ed.) Teorija i poetika prevođenja. Beograd: Prosveta, 119 - 139.

Kostić, V. (1994). "The Sonnet in English Poetry" in Stvaralaštvo Viljema Šekspira I, Beograd: Srpska književna zadruga, 83-107.

Landry, H. (1963) Interpretations in Shakespeare's sonnets. Berkeley: University of California Press.

Levin, P (ed.) (2001). The Penguin Book of the Sonnet: 500 Years of a Classic Tradition in English. Penguin Books.

Mabillard, Amanda. Introduction to Shakespeare's Sonnets. Shakespeare Online. 20 Aug. 2000. (information accessed on, informaciji pristupljeno 14. februara 2012) < http://www.shakespeare-online.com/sonnets/ sonnetintroduction.html $>$.

Martin, Philip J. T. (1972). Shakespeare's Sonnets: Self, Love and Art. Cambridge: Cambridge University Press.

Nejgebauer, A. (1971). Tradicionalno i individualno u Šekspirovim Sonetima I-II. Novi Sad.

Pound, E. (1912) Ripostes. Swift \& Co.

Rajić, Lj. (ed.) (1981). Teorija i poetika prevođenja . Beograd: Prosveta.

Rajić, Lj. (1981). "O prevođenju s prevoda" in: Rajić, Lj. (ed.) (1981) Teorija i poetika prevođenja. Beograd: Prosveta, 201-218.

Sekulić, I. (1966). Eseji i članci. Novi Sad: Matica srpska.

Šekspir, V. (1966).Poeme i soneti (second edition) Beograd: Kultura. Prepev: Danko Angjelinović.

Šekspir, V. Soneti. (1966). Prepev: Stevan Raičković po proznom prevodu Živojina Simića. Beograd: Prosveta.

The Shakespeare Glossary available at: http://www.shakespeare-online. com/glossary/

Shakespeare, William. Poems and sonnets: Booklover's Edition. Ed. The University Society and Israel Gollancz. New York: University Society Press, 1901. Shakespeare Online. 20 Aug. 2009. (information accessed on, pristupljeno informacji 14. februara 2012) < http://www. shakespeare-online.com/sonnets/sonnetthemes.html $>$.

Vilson, Dž. D. (1959). Suština o Šekspiru (The Essential Shakespeare). Trans. Borivoje Nedić. Beograd: Kultura 
Vivian, P. (1900) A dictionary of literary terms. London: G. Routledge \& sons. Wilson, J. D. (ed.) (1969). Shakespeare, William. The Works of Shakespeare. Cambridge: Cambridge University Press.

Wright, G. T. (1988). Shakespeare's Metrical Art. Berkeley: University of California Press

Živojinović, B. "Beleške o prevođenju" in: Rajić, Lj. (ed.) Teorija i poetika prevođenja (1981). Beograd: Prosveta, 261-278.

Received: 3 July 2014

Accepted for publication: 1 December 2014

Јелисавета Милојевић

\author{
РАЗМРСИТИ ЧВОР: ШЕКСПИРОВИ СОНЕТИ 27 И 144 \\ У ПРЕВОДИМА НА СРПСКИ
}

\title{
Сажетак
}

Рад се бави рашчитавањем Шекспирових Сонета 27 и 144, одабраних због изразите и пребогате полисемичности, и, отуда, крајње захтевних за превођење. Анализира се оригинал и постојећи преводи на српски, пореде се и вреднују преводна решења. Даје се и ауторов превод ових сонета, који се први пут објављује на овом месту. Апострофирају се кључне теме из области критике превода, испитују се границе песничке слободе у препеву, а поручује се да је експертско знање нужно да би се на њега наслонио таленат. Критичар превода мора императивно стати у одбрану незаштићеног ауторитета песника, који има право на своју мисао и свој израз.

Кључне речи: сонети, анализа, превод, критика превода, песничка слобода 